\title{
Phylogenetic and Genetic Relationships of Mesorhizobium tianshanense and Related Rhizobia
}

\author{
ZHI-YUAN TAN, ${ }^{1}$ XIAO-DONG XU, ${ }^{1}$ EN-TAO WANG, ${ }^{1,2}$ JUN-LIAN GAO, ${ }^{1}$ \\ ESPERANZA MARTINEZ-ROMERO, ${ }^{2}$ AND WEN-XIN CHEN ${ }^{1 *}$ \\ Department of Microbiology, College of Biological Sciences, China Agricultural University, \\ Beijing 100094, People's Republic of China, ${ }^{1}$ and Centro de Investigacion sobre Fijacion \\ de Nitrogeno, Universidad Nacional Autonoma de Mexico, Cuernavaca, Morelos, Mexico ${ }^{2}$
}

\begin{abstract}
The genetic and phylogenetic relationships for strains of Mesorhizobium tianshanense and its relatives were compared by an analysis of the results of sodium dodecyl sulfate-polyacrylamide gel electrophoresis (SDSPAGE) of whole-cell proteins, DNA-DNA hybridization, and full 16S rRNA gene sequencing. The strains of $M$. tianshanense formed a cluster which was distinct from those of other rhizobium species in the clustering analysis of SDS-PAGE. DNA-DNA relatedness between A-1BS (type strain of $M$. tianshanense) and the type or reference strains for Mesorhizobium loti, M. huakuii, M. ciceri, M. mediterraneum, and cluster U, an unnamed rhizobial group, ranged from 4.4 to $43.8 \%$. The phylogenetic analysis based on the $16 \mathrm{~S}$ rRNA gene sequences showed that $M$. tianshanense was closely related to the Mesorhizobium phylogenetic branch and could be distinguished from the other four species in this branch. These results further confirmed that these bacteria constitute a distinct rhizobial species.
\end{abstract}

The genetic approaches now widely applied to the taxonomy of root nodule bacteria have opened the possibility to infer their phylogenies and to correctly define the species and genera of these bacteria. The improved methods for identifying bacteria and a growing interest in characterization of new rhizobial isolates have brought about many changes in the taxonomy of rhizobia since 1984; a revised taxonomic system for these bacteria was proposed in "Bergey's Manual of Systematic Bacteriology" (16). Several reviews on the development of rhizobial taxonomy and phylogeny have been published recently $(20,33)$. The main developments include the descriptions of the genera Azorhizobium (8), Sinorhizobium (4, $6)$, and Mesorhizobium $(14,18)$, as well as many new species. Up to now, six distinct phylogenetic branches, Azorhizobium, Bradyrhizobium, the Rhizobium-Agrobacterium rhizogenes branch, Mesorhizobium (14), the Rhizobium galegae-Agrobacterium branch, and Sinorhizobium, have been identified, and all of them were located in the alpha subclass of Proteobacteria (6, 31-33). Mesorhizobium has been proposed recently by Jarvis et al. (14), and five species, $M$. loti (15), M. huakuii (3), M. ciceri (23), M. mediterraneum (22), and $M$. tianshanense (2) were included on the basis of the data from full sequences of $16 \mathrm{~S}$ rRNA genes. A group of rhizobia named cluster $U$ has been classified in this genus by $16 \mathrm{~S}$ ribosomal DNA (rDNA) sequencing (6). Some isolates from nodules of Amorpha fruticosa also belong to it, as indicated by the PCR-based restriction fragment length polymorphism patterns of their $16 \mathrm{~S}$ rDNA (unpublished data). M. tianshanense was described in our previous paper dealing with a group of rhizobia isolated from saline and arid soils in the Xinjiang region of China (2). Some of the strains in this species grow as slowly as Bradyrhizobium spp. Other strains grow faster than Bradyrhizobium but slower than Rhizobium leguminosarum. According to the data from the partial 16S rDNA sequence, this species belongs to the $M$. loti-M. huakuii branch (2). But its exact taxonomic and phylo-

* Corresponding author. Mailing address: Department of Microbiology, College of Biological Sciences, China Agricultural University, Beijing 100094, People's Republic of China. Phone: (86) 10-62631854. Fax: (86) 10-62582128. E-mail: wenxin@public.east.cn.net. genetic positions were controversial since the partial sequence of $M$. tianshanense A-1BS ${ }^{\mathrm{T}}$ is identical to that of $M$. ciceri (18) and since the DNA-DNA relatedness between this species and some newly emerged species had not been determined. Also, the phylogenetic relationships based on the partial and the full sequences $(31,32,34)$ may not be the same for some species, such as for Rhizobium galegae.

Currently, polyphasic taxonomy, including phenotypic and genotypic characterizations, is emphasized for classification of rhizobia (12). In order to confirm the taxonomic and phylogenetic positions of $M$. tianshanense, we performed an analysis of the full-length sequence of the 16S rRNA gene for A-1BS, the type strain of $M$. tianshanense. The DNA-DNA hybridization and whole-cell protein electrophoresis tests were also done for other $M$. tianshanense strains and some reference strains. The electrophoretic patterns of proteins have been widely used in bacterial classification, and different techniques have been developed $(17,21,25)$. It has been proved that protein profiles can provide a level of discrimination similar to or slightly higher than that of DNA-DNA hybridization studies.

\section{MATERIALS AND METHODS}

Bacterial strains. The tested strains are listed in Table 1. All strains of $M$. tianshanense were characterized in our previous research (2) and maintained in $20 \%(\mathrm{vol} / \mathrm{vol})$ glycerol-water solution at $-20^{\circ} \mathrm{C}$. The bacteria were grown on yeast mannitol agar $(28)$ medium at $28^{\circ} \mathrm{C}$.

Sodium dodecyl sulfate-polyacrylamide gel electrophoresis (SDS-PAGE) of whole-cell proteins. Bacterial strains were grown at $28^{\circ} \mathrm{C}$ for 2 days in flasks on tryptone-yeast extract medium, which contained (per liter) $5 \mathrm{~g}$ of tryptone (Oxoid), $3 \mathrm{~g}$ of yeast extract (Oxoid), $0.7 \mathrm{~g}$ of $\mathrm{CaCl}_{2} \cdot 2 \mathrm{H}_{2} \mathrm{O}(\mathrm{pH} 6.8-7.0)$. Then each culture was centrifuged at $12,000 \times \mathrm{g}$ for $3 \mathrm{~min}$. The pellet was washed once in $10 \mathrm{mM}$ Tris-HCl, $\mathrm{pH} 7.6$, and the cells were suspended in $0.5 \mathrm{ml}$ of $10 \mathrm{mM}$ Tris- $\mathrm{HCl}, \mathrm{pH} 7.6(21)$. The concentration of protein was adjusted to achieve an optical density at $280 \mathrm{~nm}$ of 1.0 in an ultraviolet spectrophotometer. After ultrasonic disruption on ice for $30 \mathrm{~s}$ with a microtip probe at $40 \mathrm{~W}, 2 \times$ treatment buffer $(0.5 \mathrm{~g}$ of SDS, $3 \mathrm{ml}$ of glycerol, $1 \mathrm{ml}$ of 2-mercaptoethanol, $4 \mathrm{mg}$ of bromophenol blue, $2 \mathrm{ml}$ of $1 \mathrm{M}$ Tris-hydrochloride, and distilled water for a final volume of $10 \mathrm{ml}$ at $\mathrm{pH} 6.8$ ) was added. The samples were stored at $-20^{\circ} \mathrm{C}$ for as long as 1 week before being analyzed by electrophoresis. The SDS-polyacrylamide gel ( 200 by $200 \mathrm{~mm}$ and $1 \mathrm{~mm}$ thick) and a shark's tooth comb were used for electrophoresis. The samples were incubated at $100^{\circ} \mathrm{C}$ for 2 min before the gel was run. Twenty-five samples per gel were subjected to discontinuous slab gel electrophoresis in an SDS-Tris-glycine buffer system, as described by Laemml (17). The protein patterns were visualized by silver staining (25). The bands of protein for each strain were scanned with a Densitometer Extra-Scanner (LKB 
TABLE 1. List of bacterial strains examined

\begin{tabular}{|c|c|c|c|}
\hline Strain $^{a}$ & Host & Origin $^{h}$ & Source $^{c}$ \\
\hline M. loti NZP 2213 & Lotus coniculatus & New Zealand & NZP \\
\hline M. ciceri USDA 3378 & Cicer arietinum & & USDA \\
\hline M. mediterraneum USDA 3392 & Cicer arietinum & & USDA \\
\hline Cluster U USDA 4413 & Acacia senegal & Senegal & USDA \\
\hline S. meliloti USDA 1002 & Medicago sativa & United States & USDA \\
\hline R. leguminosarum USDA 2370 & & United States & USDA \\
\hline R. tropici CIAT 899 & Phaseolus vulgaris & & CNPBS \\
\hline R. galegae HAMBI 540 & Galega orientalis & Finland & HAMBI \\
\hline M. huakuii CCBAU 2609 & Astragalus sinicus & Nanjing & CCBAU \\
\hline S. fredii USDA 205 & Glycine soja & Henan & USDA \\
\hline B. japonicum USDA 6 & Glycine $\max$ & United States & USDA \\
\hline B. japonicum SEMIA 5601 & Glycine $\max$ & Brazil & SEMIA \\
\hline B. japonicum SEMIA 5079 & Glycine $\max$ & Brazil & SEMIA \\
\hline \multicolumn{4}{|l|}{ M. tianshanense strains } \\
\hline $\mathrm{A}-1 \mathrm{BS}^{\mathrm{T}}$ & Glycyrrhiza pallidiflora & Xinjiang & CCBAU \\
\hline 6 & Glycyrrhiza uralensis & Xinjiang & CCBAU \\
\hline 032B & Caragana plourensis & Xinjiang & CCBAU \\
\hline 060A & Halimodendron holodendron & Xinjiang & CCBAU \\
\hline $016 \mathrm{Bm}$ & Swainsonia salsula & Xinjiang & CCBAU \\
\hline $91 \times 10$ & Halimodendron holodendron & Xinjiang & CCBAU \\
\hline $005 \mathrm{~B}$ & Sophora alopecuroides & Xinjiang & CCBAU \\
\hline $009 \mathrm{~B}$ & Glycine $\max$ & Xinjiang & CCBAU \\
\hline $91 \times 01$ & Glycine max & Xinjiang & CCBAU \\
\hline $91 \times 05$ & Sorphora alopecuroides & Xinjiang & CCBAU \\
\hline $91 \times 07$ & Sorphora alopecuroides & Xinjiang & CCBAU \\
\hline $91 \times 72$ & Sorphora alopecuroides & Xinjiang & CCBAU \\
\hline $91 \times 11$ & Caragana plourensis & Xinjiang & CCBAU \\
\hline $91 \times 09$ & Sophora alopecuroides & Xinjiang & CCBAU \\
\hline $91 \times 13$ & Glycyrrhiza sp. & Xinjiang & CCBAU \\
\hline
\end{tabular}

${ }^{a}$ Genus names not identified in the text are spelled out in the footnote to Table 2.

${ }^{b}$ Origins listed without a country are all in China.

${ }^{c}$ NZP, Division of Scientific and Industrial Research, Palmerston North, New Zealand; USDA, Beltsville Rhizobium Culture Collection, Beltsville Agricultural Research Center. Beltsville, Md.; CNPBS, Centro National de Pesquisa em Biologia do solo, Iseropedica 23851, Rio de Janeiro, Brazil; HAMBI, Culture Collection of the Department of Microbiology, University of Helsinki, Helsinki, Finland; CCBAU, Culture Collection of Beijing Agricultural University, Beijing, China; SEMIA, Equipe de Microbiologia do Solo, Instituto de Pesquisas Agronomicas (IPAGRO)-Secretaria de Agricultura, Porto Alegre, Rs, Brazil.

Co.), and a clustering analysis was performed by using the Sj coefficient and the unweighted-average linkage method (26).

DNA-DNA hybridization. The DNAs were extracted by the standard method (19). The total DNAs were digested with EcoRI restriction endonuclease and were subjected to electrophoresis in $1 \%$ agarose gels (11). For each lane, $3 \mu \mathrm{g}$ of DNA was used. A photograph of the gel was taken after staining with ethidium bromide, and then the DNAs were Southern blotted onto nitrocellulose ( $\mathrm{Hy}$ bond-N+; Amersham). The protocols specified by the manufacturer were used for Southern blotting, fixation by UV cross-linking, and hybridization at $65^{\circ} \mathrm{C}$ The random primer labeling kit (Rediprime; Amersham Life Science) and $\left.{ }^{32} \mathrm{P}\right] \mathrm{GTP}$ were used for labeling the total DNA probe from $M$. tianshanense A-1BS ${ }^{\mathrm{T}}$ by following the instructions of the manufacturer. After exposure of an $X$ ray film, the nitrocellulose with DNAs was cut into strips according to the lanes on the film. Then the strips were placed in 19-ml scintillation vials, and liquid scintillation counting was performed. The DNA-DNA homology was expressed as the percentage calculated by dividing the count for each lane by the count for the homology lane and multiplying by 100 .

Amplification and cloning of 16S rRNA gene. The total DNAs were used as a template for PCR. A large fragment of the 16S rRNA gene was amplified in $100-\mu 1$ reaction mixture by using universal forward primer P1 ( $5^{\prime}$-CGggatccAG AGTTTGATCCTGGTCAGAACGAACGCT-3', corresponding to positions 8 to 37 in Escherichia coli $16 \mathrm{~S}$ rDNA [1]) and universal reverse primer P6 (5'-C GggatccTACGGCTACCTTGTTACGACTTCACCCC-3', positions 1479 to 1506) $(31,32)$. The lowercase letters in the primer indicate the restriction site of Bam HI. The protocol described by Chun and Goodfellow (5) and a PCR kit purchased from Promega Co. (Madison, Wis.) were used. Amplified 16S rDNA was purified from $0.8 \%$ low-melting-point agarose gel by using the method of Wieslander (30). Purified rDNA and plasmid pUC18 vector were cut with $B a m \mathrm{HI}$ and ligated at $16^{\circ} \mathrm{C}$ for $16 \mathrm{~h}$. Ligated plasmids were transformed into $E$. coli $\mathrm{DH} 5 \alpha$, and transformants were selected on the basis of the results of the blue-white screening procedure (24).

DNA sequencing. Plasmids containing $16 \mathrm{~S}$ rDNA were extracted and purified according to the methods of Tiesman and Rizzino (27). Purified plasmids were sequenced by using the fmol DNA sequencing system (Promega Co.) according to the manufacturer's instructions. Six primers for sequencing were selected based on the work of Yanagi and Yamasato (32) and Willems and Collins (31).
They were P1 and P6 and an additional four primers, P2 through P5, with, respectively, the following sequences ( $E$. coli numbering system): $5^{\prime}$-GCTAGT TGGTGGGGTAA-3' (positions 247 to 263), 5'-CGTGCCAGCAGCCGCGGT $-3^{\prime}$ (positions 514 to 531), 5'-TAGATACCCTGGTAGTCC-3' (positions 799 to 806), and 5'-CCGCAACGAGCGCAACCC-3' (positions 1097 to 1115).

Analysis of sequence data. The generated rDNA sequence and those of reference strains (obtained from the EMBL, GenBank, and DDBJ data Libraries) were aligned pairwise, and the similarities were calculated and converted to a distance matrix with the Jukes-Cantor coefficient in the DNADIST program (PHYLIP version 3.572c) (10). Deletions and insertions of more than one base length were counted as one change. A dendrogram was produced by the neighbor-joining method of the NEIGHBOR program. Finally, an unrooted tree was generated with the DRAWTREE program (PHYLIP version $3.572 \mathrm{c}$ ).

Nucleotide sequence accession number. The $16 \mathrm{~S}$ rDNA sequence determined in this study has been deposited in the GenBank under the accession number U71079.

\section{RESULTS AND DISCUSSION}

SDS-PAGE of whole-cell protein. In this research, 15 strains of $M$. tianshanense and 10 type or reference strains for rhizobial species were analyzed numerically, and also a computerprocessed image (BAU software, unpublished) was produced (Fig. 1).

The dendrogram in Fig. 1 showed that all $M$. tianshanense strains formed a cluster at the similarity level of $84 \%$, while the representative strains of other rhizobial species were distinguished from $M$. tianshanense and from each other. The relationships among the strains tested in this study were similar to those from DNA-DNA hybridization (2). SDS-PAGE analysis of protein provided further evidence that $M$. tianshanense strains form a unique genetic group. 


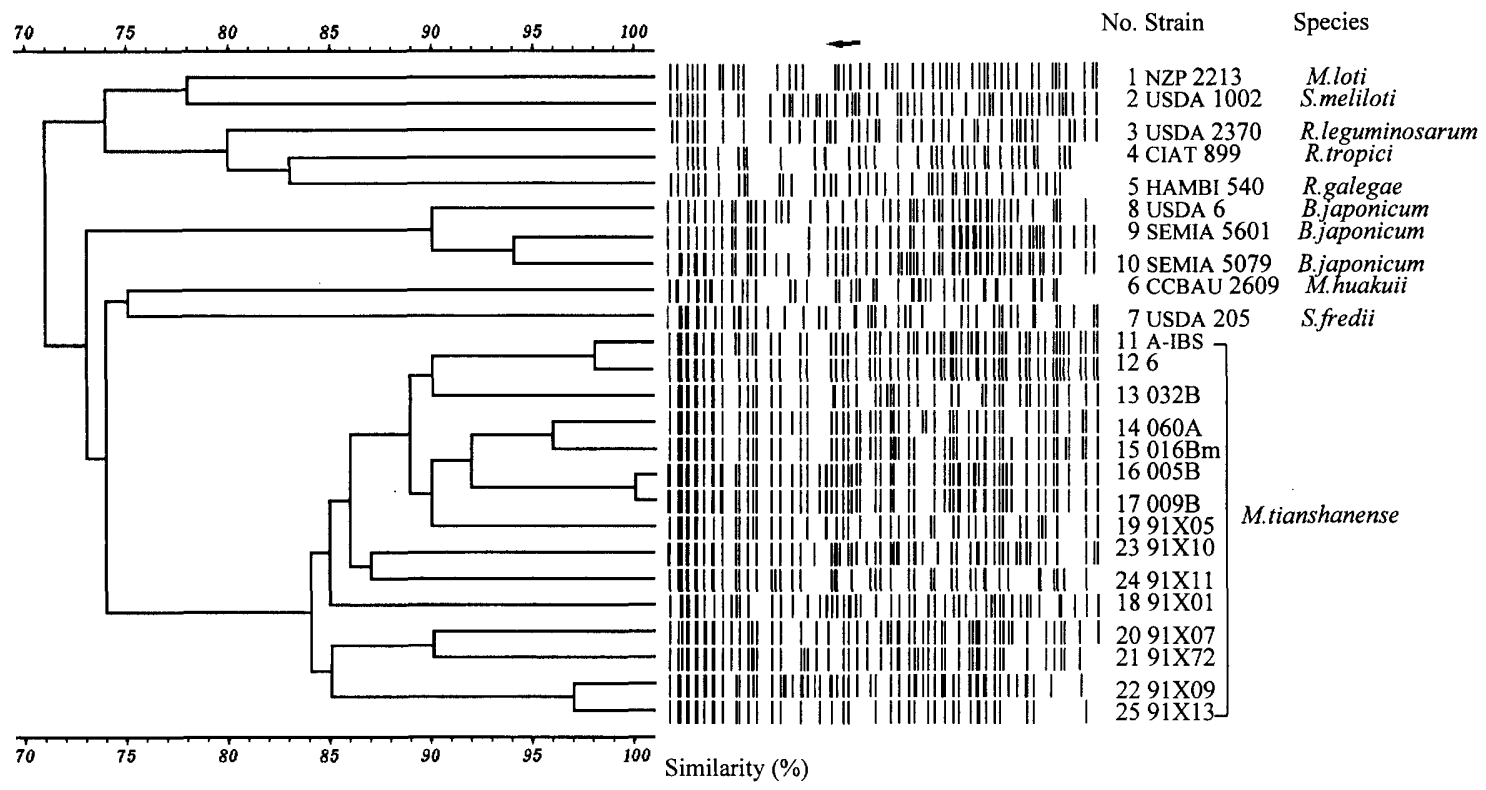

FIG. 1. Dendrogram showing the relationships among the SDS-PAGE whole-cell protein patterns of $M$. tianshanense and reference strains of Rhizobium, Bradyrhizobium, and Sinorhizobium. Computer-processed images are also shown. Genus names not introduced in the text are spelled out in the footnote to Table 2.

DNA-DNA hybridization. The DNA-DNA hybridization is an important criterion for definition of bacterial species (29), and different methods have been recommended for determining these values among rhizobia (12). Usually, the DNA-DNA relatedness among distinct species should be lower than $70 \%$, and the conservation in the ribosomal gene sequences should be lower than $95 \%$ between distinct genera, among other criteria (20). In our previous research, the spectrophotometer method described by De Ley et al. (7) was used for measuring the DNA-DNA hybridizations among the strains of $M$. tianshanense and between A-1BS, the type strain of $M$. tianshanense, and type strains for other described rhizobial species (2). The $M$. tianshanense strains formed a homologous-DNA group at the species level (DNA-DNA relatedness higher than $70 \%$ ). The DNA-DNA relatedness between A-1BS ${ }^{\mathrm{T}}$ and other type strains was lower than $70 \%$. But the relatedness between $\mathrm{A}-1 \mathrm{BS}^{\mathrm{T}}$ and $M$. huakuii CCBAU 2609 was $63.5 \%$, which was near the value of $70 \%$, one criterion used to define a species $(12,29)$. It seemed that there was no big difference between $M$. tianshanense and $M$. huakuii. As a result, the validity of $M$. tianshanense was questioned (18). In this study, Southern blotting methods (11) were used for estimating DNA-DNA hybridizations between $\mathrm{A}-1 \mathrm{BS}^{\mathrm{T}}$ and type strains for related species. The DNA-DNA relatedness between A-1BS ${ }^{\mathrm{T}}$ and type or reference strains for $M$. loti, $M$. huakuii, $M$. ciceri, $M$. mediterraneum, and cluster $U$ was $4.4,13.9,18.2,43.8$, and $35.6 \%$, respectively. And the DNA-DNA relatedness between A-1BS ${ }^{\mathrm{T}}$ and $M$. huakuii CCBAU $2609(12 \%)$ was confirmed by $\mathrm{M}$. Gillis (11a). According to these data, M. tianshanense strains form a distinct homologous-DNA group.

Nucleotide sequence analysis. The $16 \mathrm{~S}$ rRNA gene sequence of strain $\mathrm{A}-1 \mathrm{BS}^{\mathrm{T}}$ was compared with the partial sequence of the 16S rRNA gene of the same strain, as determined in the previous research (2). The alignment of the variable fragments between primers Y1 and Y2 (34) obtained in previous partial sequencing is identical with that obtained in this research. The variations among the sequences of $\mathrm{A}-1 \mathrm{BS}^{\mathrm{T}}$ and those of 27 other species in the family Rhizobiaceae and related bacteria were calculated. The similarity values are shown in Table 2.
On the basis of the $\mathrm{K}_{\text {nuc }}$ values, an unrooted phylogenetic tree (Fig. 2) was generated by the DRAWTREE program. The relationships among the described species are similar to those described in references 6 and 31 to 33. The Bradyrhizobium species formed one branch; Azorhizobium occupied the second branch; the species of Sinorhizobium constituted the third branch; the fourth branch included Rhizobium species and Agrobacterium rhizogenes; $R$. galegae and Agrobacterium species formed the fifth branch; and the Mesorhizobium branch is the sixth one. $M$. tianshanense, represented by A-1BS ${ }^{\mathrm{T}}$, fell in the Mesorhizobium branch. The similarities between $M$. tianshanense and $M$. loti, $M$. huakuii, $M$. ciceri, $M$. mediterraneum and cluster $U$ are $97.4,97.9,96.4,96.4$, and $97.4 \%$, respectively. Based on these data, it is clear that $M$. tianshanense is a member of the Mesorhizobium branch and is distinct from all of the related species. In this study, it was found that $3.6 \%$ of the base pairs of the full sequences of $16 \mathrm{~S}$ rDNAs for $M$. tianshanense and $M$. ciceri are different (Table 2), although the two species have identical sequences for a 260 -bp fragment between primers Y1 and Y2 $(14,18)$. A similar situation exists for $R$. galegae and Sinorhizobium fredii-Sinorhizobium meliloti $(31,32,34)$. Within a 260 -bp fragment, $R$. galegae is only $1.2 \%$ (3 bp) different from $M$. loti (31). But the difference is $6.3 \%$ (about 90 bp) when the full-length sequences are compared $(32,34)$. Eardley and Biever (9) reported that cluster analysis of polymorphic nucleotide sequence positions in full and partial segments of the $16 \mathrm{~S}$ rRNA genes of $R$. galegae, $M$. loti, and Agrobacterium tumefaciens revealed marked disagreement in phylogenetic tree topology depending on the portions of the genes included in the analysis. In another case, phylogenetically related rhizobial strains, such as Sinorhizobium strains, were found to have a large number of similar-but-distinct $16 \mathrm{~S}$ rDNA sequences (13). Also, some rhizobial strains, such as the type strain for Sinorhizobium saheli, have two different sequences for $16 \mathrm{~S}$ genes (13). In this case, the importance of DNA-DNA hybridization experiments in drawing the species boundaries was emphasized by Haukka et al. (13). Up to now, five species have been distinguished in the Mesorhizobium branch. 


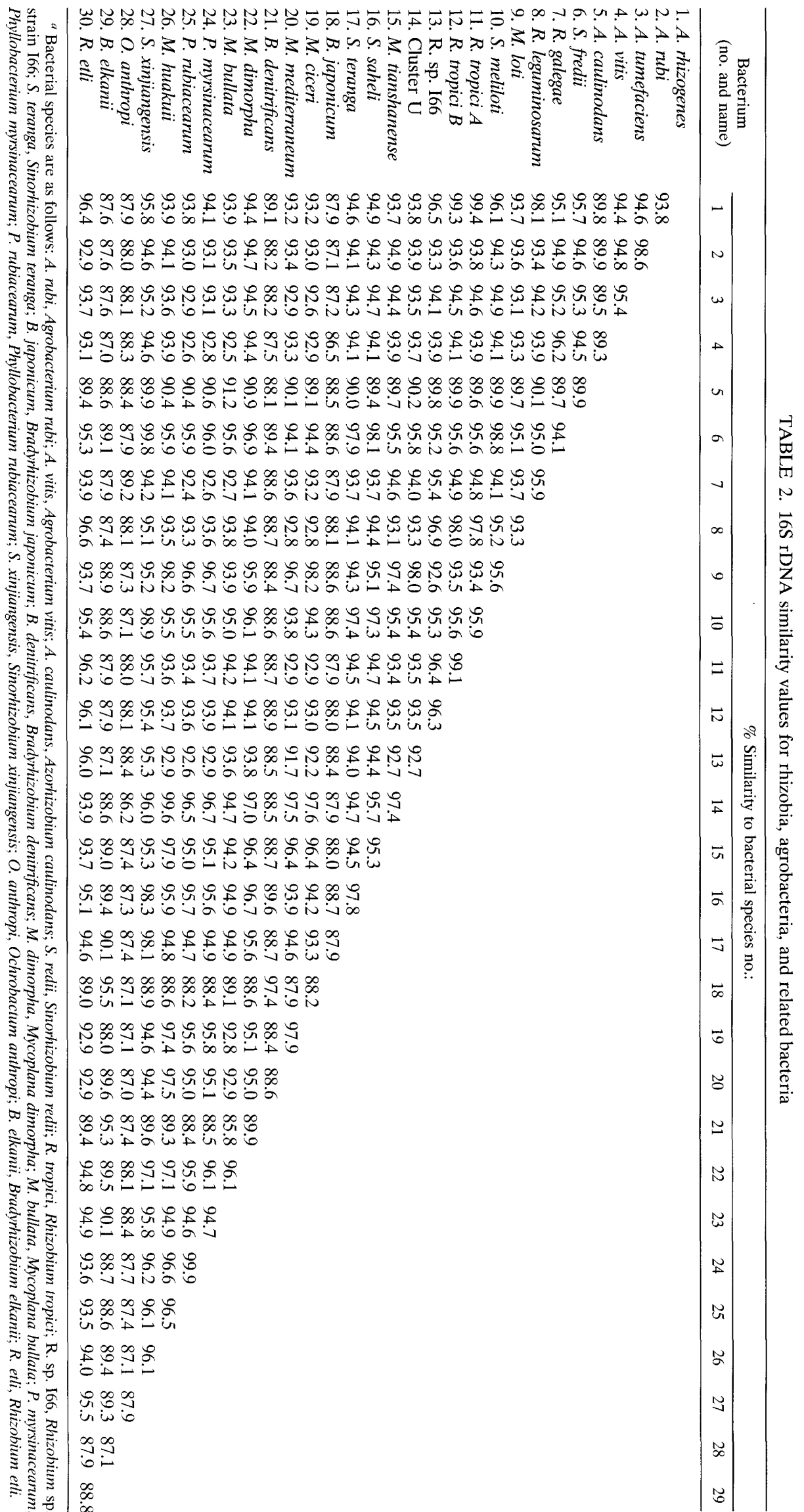




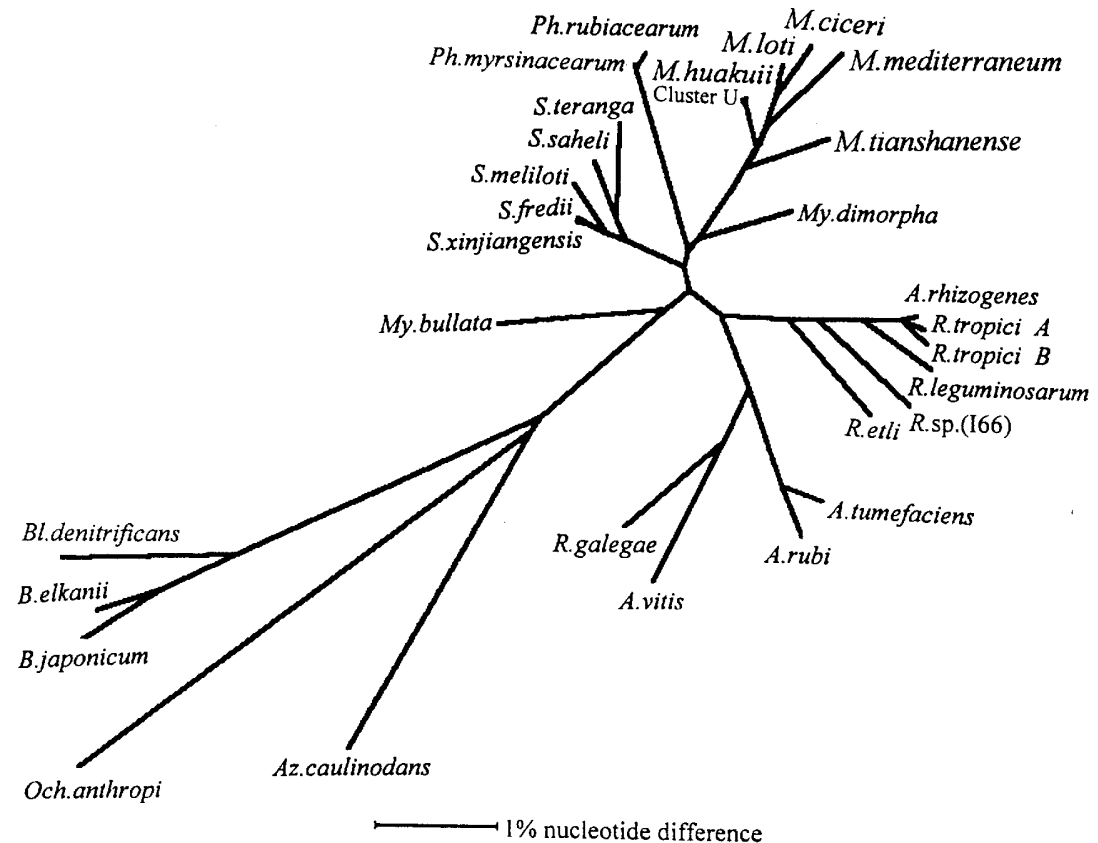

FIG. 2. Unrooted tree obtained by majority rule and strict consensus tree program PHYLIP, version 3.572c. Abbreviations: R, Rhizobium; M, Mesorhizobium; Ph, Phyllobacterium; My, Mycoplana; S, Sinorhizobium; Och, Ochrobactrum; A, Agrobacterium; Az, Azorhizobium; B, Bradyrhizobium; Bl, Blastobacter. GenBank accession numbers: A. rubi LMG 156, X67228; A. tumefaciens LMG 196, X67223; A. rhizogenes LMG 152, X67224; A. vitis LMG 8750, X67225; S. fredii LMG 6217, X67231; S meliloti LMG 6133, X67222; S. xinjiangensis IAM 14142, D12796; S. saheli LMG 7837, X68390; S. teranga LMG 6463, X68387; $R$. galegae LMG 6215, X67226; $R$. leguminosarum LMG 8820, X67227; M. loti LMG 6125, X67229; $R$. tropici B LMG 9518, X67234; $R$. tropici A LMG 9517, X67233; $R$. etli ATCC 14483, U47303; M. huakuii IAM 14158, D12791; M. ciceri UPM-Ca7, U07934; M. mediterraneum UPM-Ca36, L38825; B. japonicum LMG 6138, X66024; P. myrsinacearum IAM 13584, D12789; P. rubiacearum IAM 13587, D12790; $M$. dimorpha IAM 13154, D12786; R. sp. I66, U71078; $M$. bullata IAM 13153, D12785; O. anthropi IAM 14119, D12794; A. caulinodans LMG 6465, X67221; B. elkanii ATCC 49852, U35000; B. denitrificans LMG8443, X66025; Cluster U LMG 7836, X68389. In the above strain designations, the following abbreviations are used: LMG, Culture Collection Laboratorium voor Microbiologic, Universiteit Gent, Ghent, Belgium; IAM, Institute of Applied Microbiology, The University of Tokyo, Tokyo, Japan; ATCC, American Type Culture Collection, Rockville, Md. Genus names are spelled out either in the text or in the footnote to Table 2 .

The results in this paper and those in our previous paper (2) clearly proved that $M$. tianshanense is a distinct species in the Mesorhizobium branch.

\section{ACKNOWLEDGMENT}

This investigation was supported by the National Natural Science Foundation of China.

\section{REFERENCES}

1. Brosius, J., M. L. Palmer, P. J. Kennedy, and H. F. Noller. 1978. Complete nucleotide sequence of a $16 \mathrm{~S}$ ribosomal RNA from Escherichia coli. Proc. Natl. Acad. Sci. USA 75:4801-4805.

2. Chen, W., E. Wang, S. Wang, Y. Li, X. Chen, and Y. Li. 1995. Characteristics of Rhizobium tianshanense sp. nov., a moderately and slowly growing root nodule bacterium isolated from an arid saline environment in Xinjiang, People's Republic of China. Int. J. Syst. Bacteriol. 45:153-159.

3. Chen, W. X., G. S. Li, Y. L. Oi, E. T. Wang, H. L. Yuan, and J. L. Li. 1991 Rhizobium huakuii sp. nov. isolated from the root nodules of Astragalus sinicus. Int. J. Syst. Bacteriol. 41:275-280.

4. Chen, W. X., G. H. Yan, and J. L. Li. 1988. Numerical taxonomic study of fast-growing soybean rhizobia and a proposal that Rhizobium fredii be assigned to Sinorhizobium gen. nov. Int. J. Syst. Bacteriol. 38:392-397.

5. Chun, J., and M. Goodfellow. 1995. A phylogenetic analysis of the genus Nocardia with 16 S rRNA gene sequences. Int. J. Syst. Bacteriol. 45:240-245.

6. De Lajudie, P., A. Willems, B. Pot, D. Dewettinck, G. Maestrojuan, M. Neyra, M. D. Collins, B. Dreyfus, K. Kersters, and M. Gillis. 1994. Polyphasic taxonomy of rhizobia: emendation of the genus Sinorhizobium and description of Sinorhizobium meliloti comb. nov., Sinorhizobium saheli sp. nov., and Sinorhizobium teranga sp. nov. Int. J. Syst. Bacteriol. 44:715-733.

7. De Ley, J., H. Cattoir, and A. Reynaerts. 1970. The quantitative measurement of DNA hybridization from renaturation rates. Eur. J. Biochem. 12: 133-142.

8. Dreyfus, B., J. L. Garcia, and M. Gillis. 1988. Characterization of Azorhizobium caulinodans gen. nov., sp. nov., a stem-nodulating nitrogen-fixing bac- terium isolated from Sesbania rostrata. Int. J. Syst. Bacteriol. 38:89-98.

9. Eardley, B. D., and M. A. Biever. 1995. Potential chimeras in the 16S rRNA genes of Rhizobium and other genera. Presented at the 15th North American Conference on Symbiotic Nitrogen Fixation, North Carolina State University, Raleigh, N.C., 13 to 17 August, 1995.

10. Felsenstein, J. 1993. PHYLIP-(Phylogeny Inference Package), version 3.572c. Department of Genetics, University of Washington, Seattle, Wash.

11. Flores, M., V. Gonzalez, M. A. Pardo, A. Leija, E. Martinez, D. Romero, D. Pinero, G. D. Eavila, and R. Palacios. 1988. Genomic instability in Rhizobium phaseoli. J. Bacteriol. 170:1191-1196.

11a.Gillis, M. Personal communication.

12. Graham, P. H., M. J. Sadowsky, H. H. Keyser, Y. M. Barnet, R. S. Bradley, J. E. Cooper, J. De Ley, B. D. W. Jarvis, E. B. Roslycky, B. W. Strijdom, and J. P. W. Young. 1991. Proposed minimal standards for the description of new genera and species of root- and stem-nodulating bacteria. Int. J. Syst. Bacteriol. 41:582-587.

13. Haukka, K. E., K. Lindstrom, and J. P. W. Young. 1996. Diversity of partial 16S rRNA sequences among and within strains of African rhizobia isolated from Acacia and Prosopis. Syst. Appl. Microbiol. 19:352-359.

14. Jarvis, B. D. W., P. Van Berkum, W. X. Chen, S. M. Nour, M. P. Fernandez, J. C. Cleyet-Marel, and M. Gillis. 1997. Transfer of Rhizobium loti, Rhizobium huakuii, Rhizobium cicer, Rhizobium mediterraneum, and Rhizobium tianshanense to Mesorhizobium gen. nov. Int. J. Syst. Bacteriol. 47:895-898.

15. Jarvis, B. D. W., C. E. Pankhurst, and J. J. Patel. 1982. Rhizobium loti, a new species of legume root nodule bacteria. Int. J. Syst. Bacteriol. 32:378-380.

16. Jordan, D. C. 1984. Family III. Rhizobiaceae Conn 1938 , 321 AL, p. 234-242. In N. R. Krieg and J. G. Holt (ed.), Bergey's manual of systematic bacteriology, vol. 1. Williams and Wilkins Co., Baltimore, Md.

17. Laemmli, U. K. 1970 . Cleavage of structural proteins during the assembly of the head of bacteriophage T4. Nature (London) 227:680-685.

18. Lindström, K., P. van Berkum, M. Gillis, E. Martinez, N. Novikova, and B. Jarvis. 1995. Report of the round table on Rhizobium taxonomy, p. 807-810. In I. A. Tikhonovich, N. A. Provorov, V. I. Romanov, and W. E. Newton (ed.), Nitrogen fixation: fundamentals and applications. Kluwer Academic Publishers, Dordrecht, The Netherlands.

19. Marmur, J. 1961. A procedure for the isolation of deoxyribonucleic acid from microorganisms. J. Mol. Biol. 3:208--218. 
20. Martinez-Romero, E., and J. Caballero-Mellado. 1996. Rhizobium phylogenies and bacterial genetic diversity. Crit. Rev. Plant. Sci. 15:113-140.

21. Noel, K. D., and W. J. Brill. 1980. Diversity and dynamics of indigenous Rhizobium japonicum. Appl. Environ. Microbiol. 40:931-938.

22. Nour, S. M., J.-C. Cleyet-Marel, P. Normand, and M. P. Fernandez. 1995 Genomic heterogeneity of strains nodulating chickpeas (Cicer arietinum L.) and description of Rhizobium mediterraneum sp. nov. Int. J. Syst. Bacteriol. 45:640-648.

23. Nour, S. M., M. P. Fernandez, P. Normand, and J.-C. Cleyet-Marel. 1994. Rhizobium ciceri sp. nov., consisting of strains that nodulate chickpeas (Cicer arietinum L.). Int. J. Syst. Bacteriol. 44:511-522.

24. Sambrook, J., E. F. Fritsch, and T. Maniatis. 1989. Molecular cloning: a laboratory manual, 2nd ed. Cold Spring Harbor Laboratory Press, Cold Spring Harbor, N.Y.

25. Smammons, D. W., L. D. Adams, and E. E. Nishizawa. 1981. Ultrasensitive silver based color staining of polypeptides in polyacrylamide gels. Electrophoresis 2:135.

26. Sneath, P. H. A., and R. R. Sokal. 1973. Numerical taxonomy: the principle and practices of numerical classification. W. H. Freeman \& Co., San Francisco, Calif.

27. Tiesman, J., and A. Rizzino. 1991. A rapid and reliable method for the purification of high-quality plasmid DNA for double strand sequencing. BioTechniques 10:319-328.
28. Vincent, J. M. 1970. A manual for the practical study of root-nodule bacteria, p. 73-97. International Biological Program handbook 15. Blackwell Scientific Publications, Ltd., Oxford, United Kingdom.

29. Wayne, L. G., D. J. Brenner, R. R. Colwell, P. A. D. Grimont, O. Kandler, M. I. Krichevsky, L. H. Moore, W. E. C. Moore, R. G. E. Murray, E. Stackebrandt, M. P. Starr, and H. G. Truper. 1987. Report of the ad hoc committee on reconciliation of approaches to bacterial systematics. Int. J. Syst. Bacteriol. 37:463-464.

30. Wieslander, L. 1979. A simple method to recover intact high molecular weight RNA and DNA after electrophoretic separation in low melting tem perature agarose gels. Anal. Biochem. 98:305.

31. Willems, A., and M. D. Collins. 1993. Phylogenetic analysis of rhizobia and agrobacteria based on 16S rRNA gene sequences. Int. J. Syst. Bacteriol. 43:305-313.

32. Yanagi, M., and K. Yamasato. 1993. Phylogenetic analysis of the family Rhizobiaceae and related bacteria by sequencing of 16S rRNA gene using PCR and DNA sequencer. FEMS Microbiol. Lett. 107:115-120.

33. Young, J. P. W., and K. E. Haukka. 1996. Diversity and phylogeny of rhizobia. New Phytol. 133:87-94.

34. Young, J. P. W., H. L. Downer, and B. D. Eardly. 1991. Phylogeny of the phototropic Rhizobium strain BTAil by polymerase chain reaction-based sequencing of a 16S rRNA gene segment. J. Bacteriol. 173:2271-2277. 